\title{
Application of coniferous dendroforms for biotesting of coastal urban environments
}

\author{
$M$ Kosovskaya $^{1, *}, N$ Lyamina $^{1}, E$ Semenova $^{1,2}, I$ Tsokalo $^{2}, N$ Gnilomedova $^{1}$, and $A$ \\ Kuzmin $^{1}$ \\ ${ }^{1}$ Sevastopol State University, 33, Universitetskaya Street, 299015, Sevastopol, Russia \\ ${ }^{2}$ V.I. Vernadsky Crimean Federal University, 295007, Akademika Vernadskogo Avenue, 4, \\ Simferopol, Russia
}

\begin{abstract}
In the urban environment, the main sources of pollutants entering the atmosphere are the work of industrial enterprises and the operation of vehicles, which leads to a significant change in the composition of the air, which leads to the objective need for strict control of the state of the city's environment and atmospheric air in particular. The ongoing state monitoring control of the atmospheric air in the urban environment is not sufficient, which leads to the need to create alternative control methods. This method is bioindication and biotesting. Applying the sensitivity of organisms, one can assess the degree of environmental pollution. Thus, the choice of certain bioindicators directly affects the quality of the data obtained, especially in the areas of coastal cities. The studies were carried out in Sevastopol during 2018-2020. The results obtained make it possible to use Pinus pallasiana Lamb. as a test object for assessing the quality of the environment. Coniferous dendroforms Picea pungens Engelm. and Thuja occidentalis L. showed results that allow their use in bioindication, in the case of using the entire possible spectrum of markers to increase the reliability of environmental quality assessment by biotesting methods. Previously, similar studies were carried out using deciduous dendroforms.
\end{abstract}

\section{Introduction}

The decline in the quality of atmospheric air has given rise to a number of problems associated with an increased risk of deterioration in the quality of life of urban residents. The deteriorating environmental situation in cities requires careful monitoring. Environmental monitoring is a set of measures aimed at minimizing the impact and preserving the environment. One of the most important elements of ensuring control of the state of atmospheric air are: monitoring the state of the air and predicting its changes, identifying and assessing sources of anthropogenic impact, and preventing an increased level of pollution.

When monitoring the state of atmospheric air, instrumental, instrumental and laboratory, indicator and calculation methods, or a method for monitoring emissions based

\footnotetext{
* Corresponding author: sevtania@rambler.ru
} 
on the analysis of actual air pollution are used. [1]. To analyze the state of atmospheric air, various monitoring methods for assessing pollution are used. There are many methods that allow assessing the state of the surrounding urban environment. [2]. Most often, gas analyzers and chemical methods for determining aerosol pollution are used for this. [1]. Such methods are not only expensive and laborious, but the results obtained are not always reliable for local sources of pollution. In addition, modern technical means of control are developed primarily for assessing the degree of atmospheric air pollution in stationary conditions, and the methods used for assessing from mobile sources are insufficient. The methods of physical, chemical and analytical quality control cannot always give an adequate picture of the effect of a particular substance on the ecosystem as a whole. [3]. At the same time, state control takes into account, first of all, the effect of certain substances on the state of human health, while plants react faster to changes in the composition of the air. In addition, many substances of both natural and synthetic origin are multicomponent, which complicates their physicochemical standardization.

Despite the importance of assessing the quality of the environment at all levels using various approaches (including physical, chemical, social and other aspects), biological assessment is considered a priority. A simple explanation for this may be that it is the state of various types of living beings and of man himself that is the ultimate goal of all environmental protection measures. [4]. In various areas of industry, there is an increasing need for a variety of biological tests associated with the growth of environmental problems, as well as the growing use of biological objects in practice. Biological control methods in a number of situations make it possible to quickly assess the quality of the environment and the presence of some contaminants that cannot be detected by chemical methods. The use of bioindication and biotesting methods significantly reduces the cost and speeds up the control process.

Nowadays, the studies carried out in the field of monitoring the state of atmospheric air by bioindication and biotesting methods when assessing urban environments allow a sufficiently qualitative assessment of the impact of a local source on the environment using certain test objects [5-6].

In the urban environment, the main anthropogenic sources of pollutants entering the atmospheric air are: industrial enterprises and vehicles, which leads to a significant change in the composition of the air. Carbon oxides, sulfur dioxide, nitrogen oxides, hydrocarbons, benzo(a)pyrene, as well as industrial dust, emissions from tires, etc. make up the bulk of the emitted compounds [7-8]. The whole complex of negative effects of pollutant emissions, including exgalates, leads to a reduction in the life expectancy of plants in $2 \ldots 3$ times. Thus, using the resistance of plants to the conditions of the urban environment, it is possible not only to assess the state of the atmospheric air, but also to develop certain measures to minimize the spread of aerosol pollution in time [3, 9].

The main task of bioindication is the development of methods and criteria that could adequately reflect the level of anthropogenic impacts taking into account the complex nature of pollution and diagnose early disturbances in the most sensitive components of biotic communities $[3,9]$. At the same time, the reliability of the results obtained directly depends on those objects that are used as bioindicators. Based on this, the choice of a test object that allows assessing the state of a certain territory is an urgent task.

The purpose of this work is to analyze the possibility of using coniferous dendroforms for bioindication of atmospheric air in Sevastopol.

\section{Materials and methods}

Plants, the state of which serves as an indicator of changes in the natural state of the environment or its absence, can be used as bioindicators [6]. The indicator significance of a 
particular test object is determined by the stability of the ecological system as a whole, taking into account the zone of tolerance in which the organism is able to maintain its homeostasis [10]. Any factor, if it goes beyond the 'optimum zone' for a given organism, is stressful, which leads to a response of varying intensity and duration. Moreover, the factors can be of both anthropogenic and biotic nature. The manifestation of the body's response to such a factor determines the possibility of using some object as a bioindicator. The stress factor can cause both a specific reaction of the body and a non-specific one. Such reactions can be used to identify an arbitrary factor, or the action of a single pollutant, or the complex action of anthropogenic pollution. A plant object can be sensitive to one or another contamination. This property is used in recording bioindication $[4,6]$. The sensitivity of phytoindicators makes it possible to determine the presence of a pollutant in the air by early morphophysiological reactions - a change in color or shape of a leaf plate, needles, various forms of necrosis, early wilting and falling of leaves. This reaction can be easily identified visually. Gas-resistant phytoindicators make it possible to determine the quality of the environment by the degree of accumulation of the pollutant and the response to harmful metabolic products. Such a reaction to the accumulated stress factor can be determined by the enzyme activity of plants. [4]

Thus, for bioindication and biotesting, it is necessary to use test objects that meet the following requirements $[4,6]$ :

The test object must be typical for the area. 'Classical' bioindicators typical for central Russia, such as silver birch (Betula pendula Roth.) and small-leaved linden (Tília cordátaa), show a nonspecific reaction to specific pollutants in the coastal city of Sevastopol.

Test objects should have a high abundance in the studied ecosystem. An increase in the number of objects under study increases the representativeness of the result obtained.

To determine the dynamics of contamination during accumulating bioindication, test objects must grow in a given place for a number of years.

Bioindicators used in biotesting should be in conditions suitable for sampling.

To be able to track the influence of a factor on subsequent generations, test objects must have a short period of ontogenesis.

An important characteristic of any indicator is its reliability. There are no unified generally accepted methods for assessing the reliability. In botanical and geobotanical studies, for this purpose, various scales are used to assess the degree of conjugation (joint occurrence) of the indicator and the indicated object [5]. Most often, when analyzing atmospheric air, the classification of the types of test objects divided by the purpose of the indication, given by Rovell [4], is used:

- environmental indicators providing information about the ecological environment on the presence and/or number of species and populations;

- evaluation indicators used to determine the value of a territory in terms of nature conservation or habitat quality, to what extent its conservation value is related to it;

- performance indicators are used to object the goals of strategies, action plans and projects [4].

Deciduous dendroforms are the most convenient from the point of view of use for all purposes. Modern scholars offer the following species of deciduous woody plants as bioindicator species: silver birch (Betula pendula Roth.) (these test objects were used in the works of M.A. Klevtsova, Phan Thi Lan Anh) [11], small-leaved elm (Ulmus parvifolia) (Tarasova T.F.) [12], wild apple (Málus sylvéstris) (Pavlyuk P.A) [13], ash-leaved maple (Ácer negúndo) (Onofreychuk O.N.) [14], European linden (Tilia europaea) (Yakisheva Yu. E) [15], Karelian birch (B. pendula var. Carelica) (Galibina N.A.) [16], plane trees (Acer platanoides L. and Acer pseudoplatanus L) (Korshikov I.I. and Vinogradova E.N.) [17]. The possibilities of using various enzymes as parameters of bioindication are most widely described in the works of V.S. Nikolaevsky [19]. As for conifers, the use of Scots 
pine (Pínus sylvéstris) (Gruudeva L.I., Tinnikova A.V., Milyutina I.L., Neverova O.A. $[18,19,6,20,21]$ and spruce common (Picea abies) (Davydova N. Yu) [22] is usually proposed.

Such trees grow in limited numbers in the southern region. According to the results of many years of research, it was revealed that the use of these bioindicators is not advisable. Sevastopol and the Crimean region are characterized by the growth of a large number of conifers. Coniferous dendroforms are convenient because they can serve as bioindicators all year round. In forestry, an assessment of the state of the environment by a complex of characters in conifers has been developed, in which not only morphological indicators, which are very variable, are used, but also a number of biochemical changes. [23-26]. Their use is informative in small areas (for example, the impact of the road on the adjacent zone in urban ecosystems of different ranks) and on large ones (for example, the use of coniferous forest plantations to assess the atmospheric air of a region) [27].

In the course of the study, laboratory and field research methods were used.

\section{Results and discussion}

To assess the possibility of using coniferous plants as bioindicators in the territory of Sevastopol, an integral assessment of the state of the atmospheric air was carried out. The assessment was carried out using statistical monitoring data [7] and the results of many years of studies using bioindication methods [28,29]. Experimentally, data were obtained using black poplar (Pópulus nígra), robinia pseudoacacia (Robínia pseudoacácia) and small-leaved linden (Tília cordáta) as bioindicators of pollution. Based on the results of the data obtained, 12 points were selected with varying degrees of anthropogenic load in each of the districts of Sevastopol. A conditionally selected control point was chosen, which is characterized by the least number of mobile sources of impact on the atmospheric air.

For sampling, 13 points were selected with varying degrees of anthropogenic impact. $\mathrm{T}_{1}$ - intersection of Gorpishchenko and Kostromskaya streets (average traffic intensity, circular traffic, a large number of residential buildings nearby); $\mathrm{T}_{2}$ - Istomin street (characterized by an average traffic intensity); $\mathrm{T}_{3}$ - intersection of Heroes of Sevastopol and Nikolai Ostrovsky streets (characterized by an average traffic volume); $\mathrm{T}_{4}$ - Vakulenchuk street (heavy traffic, circular traffic, next to a gas station, two traffic lights and four pedestrian crossings); $\mathrm{T}_{5}-$ Stepanyan street (moderate traffic intensity, pedestrian crossing and gas station); $\mathrm{T}_{6}-$ Kombat Neustroev square (average traffic intensity, the presence of three pedestrian crossings, there is a bay nearby, a circular traffic); $\mathrm{T}_{7}$ - Oleg Koshevoy street (characterized by heavy traffic, there is a gas station near the sampling point; traffic light and pedestrian crossing); $T_{8}$ - General Ostryakov avenue (School No. 22 named after N.A. Ostryakov) (this point is characterized by heavy traffic in the morning, there is also a traffic light and a pedestrian crossing); $\mathrm{T}_{9}$ - SevGorRynKhoz 5th kilometer (characterized by heavy traffic throughout the day, 3 traffic lights and 4 pedestrian crossings, there is a final stop nearby); $T_{10}$ - Stroitelnaya street (characterized by an average traffic intensity, there is a pedestrian crossing, a garage cooperative near the sampling point); $\mathrm{T}_{11}$ - Krestovskiy street (characterized by an average traffic intensity, next to the sampling point, there is a gas station, railway tracks with a barrier); $\mathrm{T}_{12}$ - intersection of Krestovskiy and Terletskiy streets (characterized by an average traffic intensity, there is a bus stop near the sampling point, a branch of the Ministry of Emergencies); $T_{13}$ (conditionally control point) Kurchatov street, on the territory of the park of the Institute of Nuclear Energy and Industry (characterized by a weak traffic intensity).

Based on the data obtained, a histogram of ranking points was constructed depending on the degree of anthropogenic load. The cleanest point is point 5 (Stepanyan street), the most polluted point is point 9 (SevGorRynKhoz 5th km), (Fig. 1). The scoring was carried out 
according to the created ranking system [9]. The sources of anthropogenic load at all selected points were cars and objects of the energy industry.

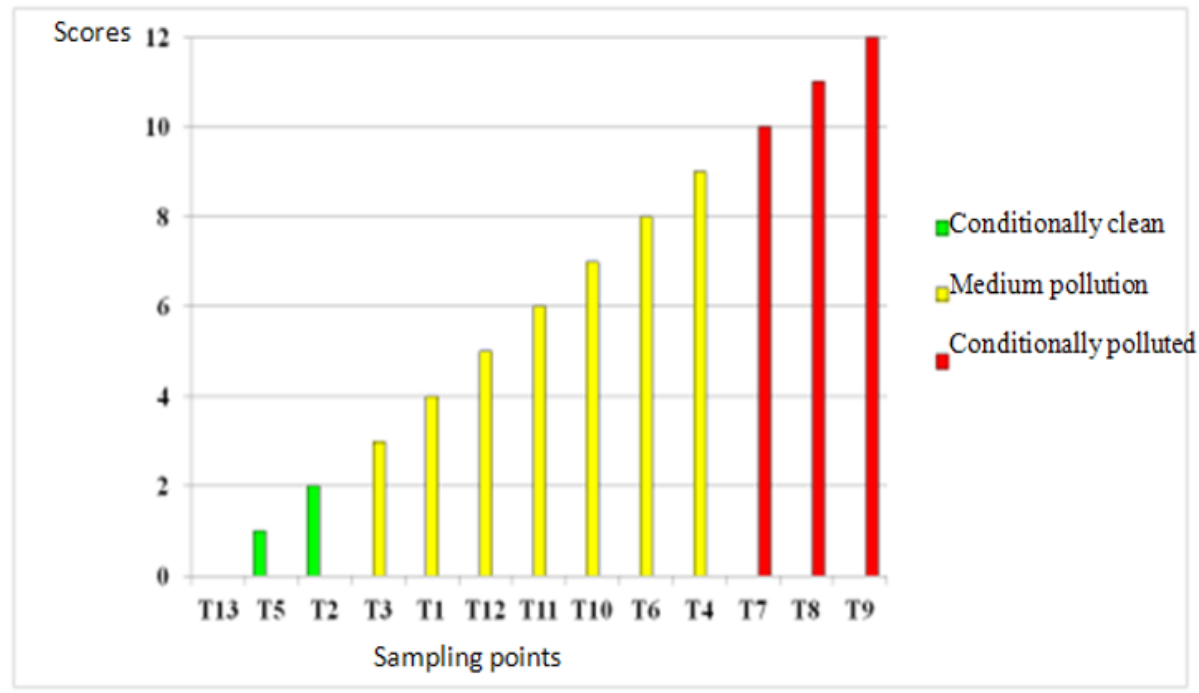

Fig. 1. Ranking of points depending on the degree of anthropogenic load.

As test objects, coniferous trees growing in all the studied points were selected: Crimean pine or Pallas pine (Pinus nigra subsp. Pallasiana), blue spruce (Pìcea püngens), Mediterranean cypress (Cupressus sempervirens), American arborvitae (Thúja occidentális) (Fig. 2).

Studies were carried out according to the developed methodology for the rapid assessment of atmospheric air pollution [9]. Measurements were carried out during 6 seasons from autumn 2018 to spring 2020. Sampling for analysis is carried out in September 2018, December 2018, April 2019, September 2019, December 2019, and March 2020. The analysis was carried out in the daytime, taking into account the daily anthropogenic load, in triplicate.

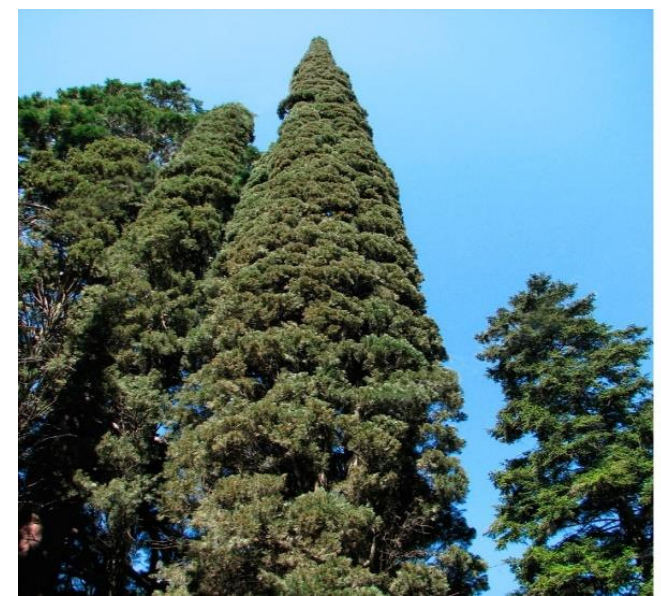

(a)

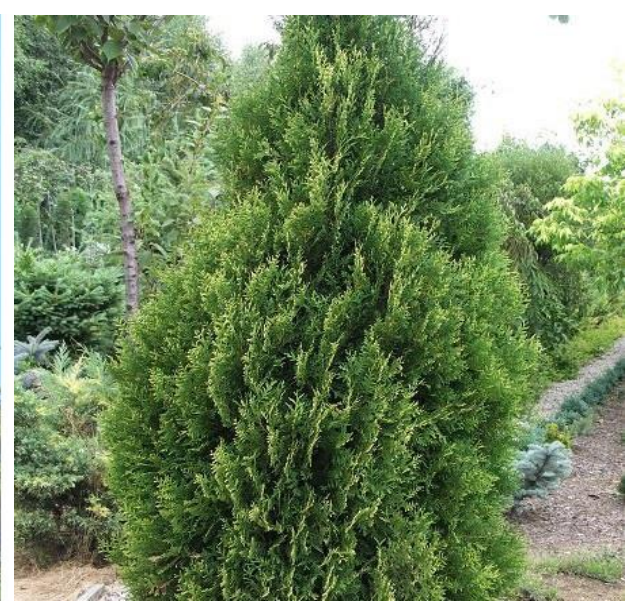

(b)

Fig. 2. Selected test objects: (a) Mediterranean cypress (Cupressus sempervirens); (b) American arborvitae (Thúja occidentális). 
At the first stage, the morphophysiological state of tree plantations at each of the selected points was analyzed. The results are shown in Fig. 3.

\section{Scores}

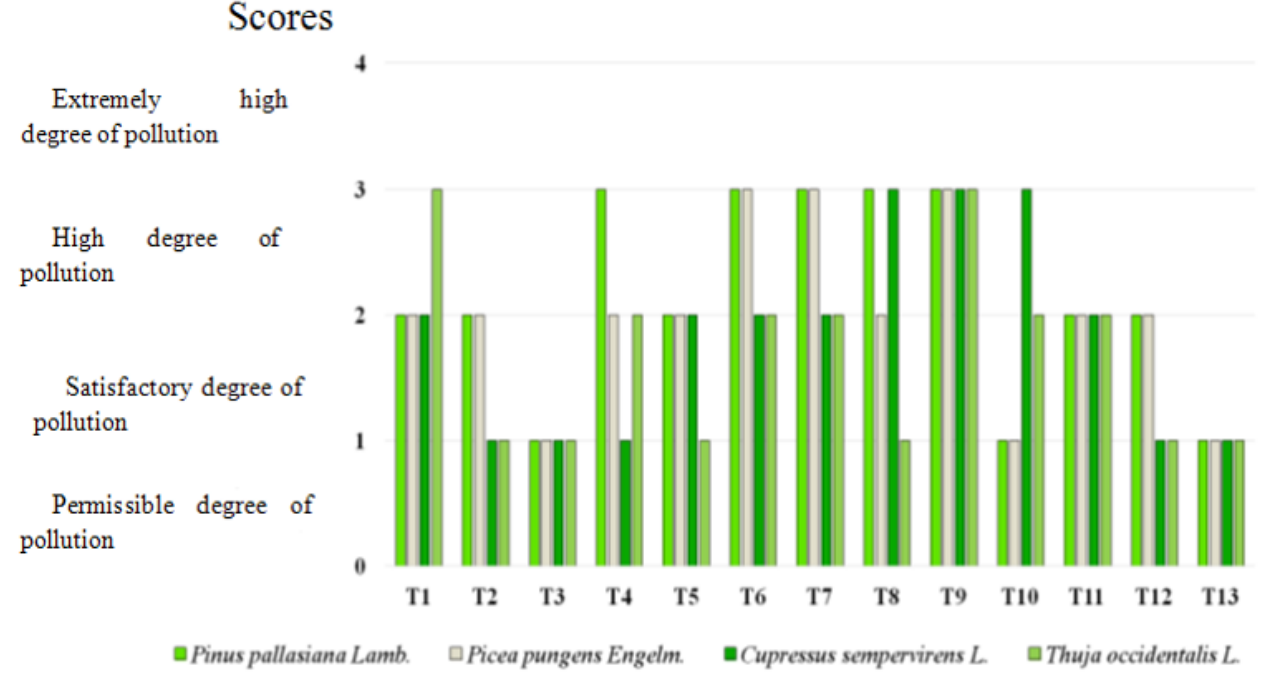

Fig. 3. Assessment of the morphophysiological state of the research objects.

The obtained results showed that when using the assessment of the vital state of the investigated dendroforms as a marker for bioindication, the Crimean pine confirms the ranking of the points, while the Mediterranian cypress did not confirm the ranking of the points.

According to the results of calculations of the fluctuating asymmetry of the needles of the studied dendroforms, the Crimean pine confirms the ranking, but the blue spruce did not confirm the ranking of the points. The summary results for all seasons are summarized in a diagram (Fig. 4).

\section{Scores}

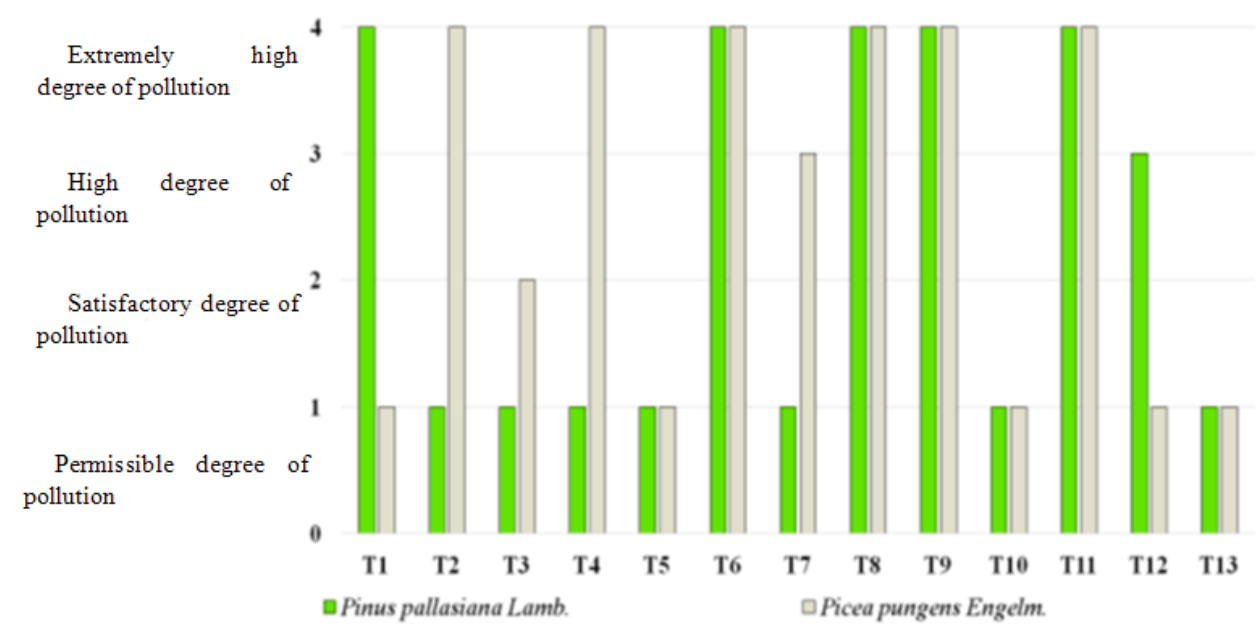

Fig. 4. Results of the analysis of the fluctuating asymmetry of needles. 
Opposite results were obtained when assessing the degree of damage and drying of the needles of the studied dendroforms [30]. The blue spruce confirms the ranking of the points, the Crimean pine did not confirm the ranking of the points (Fig. 5).

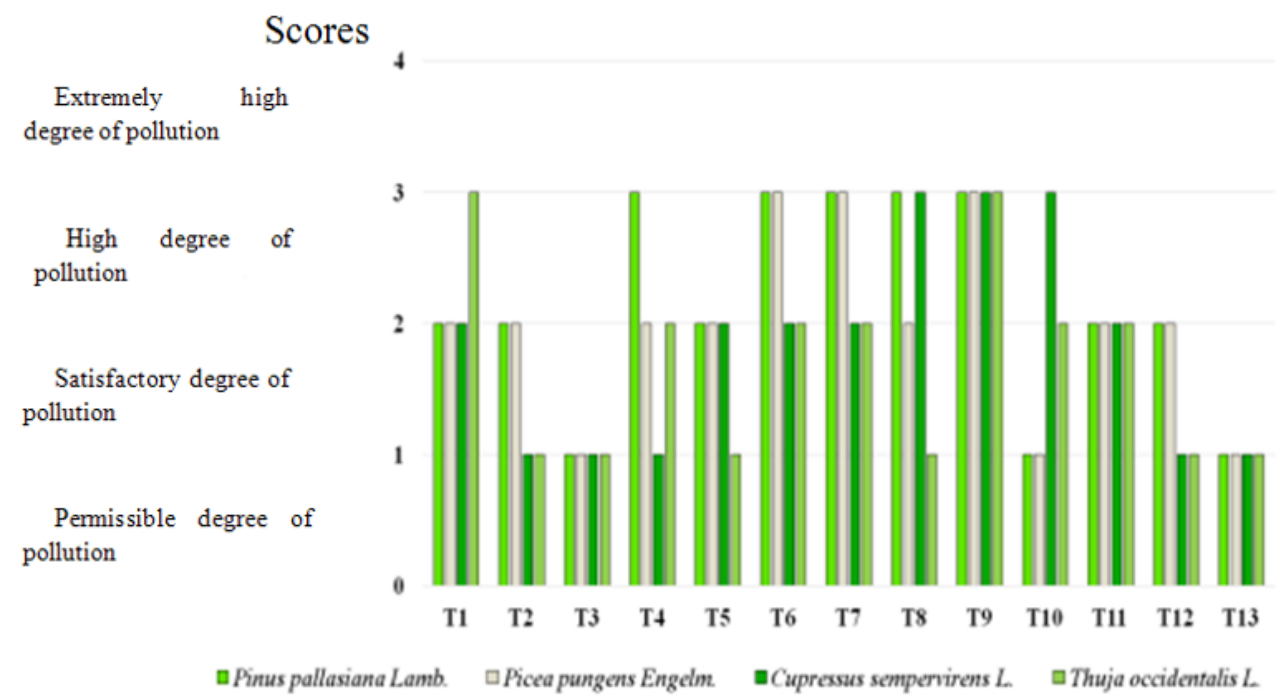

Fig. 5. Results of studies on the degree of damage and drying out of needles.

At the second stage, plant stress resistance was chosen as a marker for biotesting [31]. The enzymatic activity and vitamin content in tree plantations at each of the selected points have been analyzed.

According to the results of studies of peroxidase activity (EC 1.11.7), the Crimean pine confirms the ranking of points, but the Mediterrenian cypress did not confirm the ranking. Results are summarized in Fig. 6.

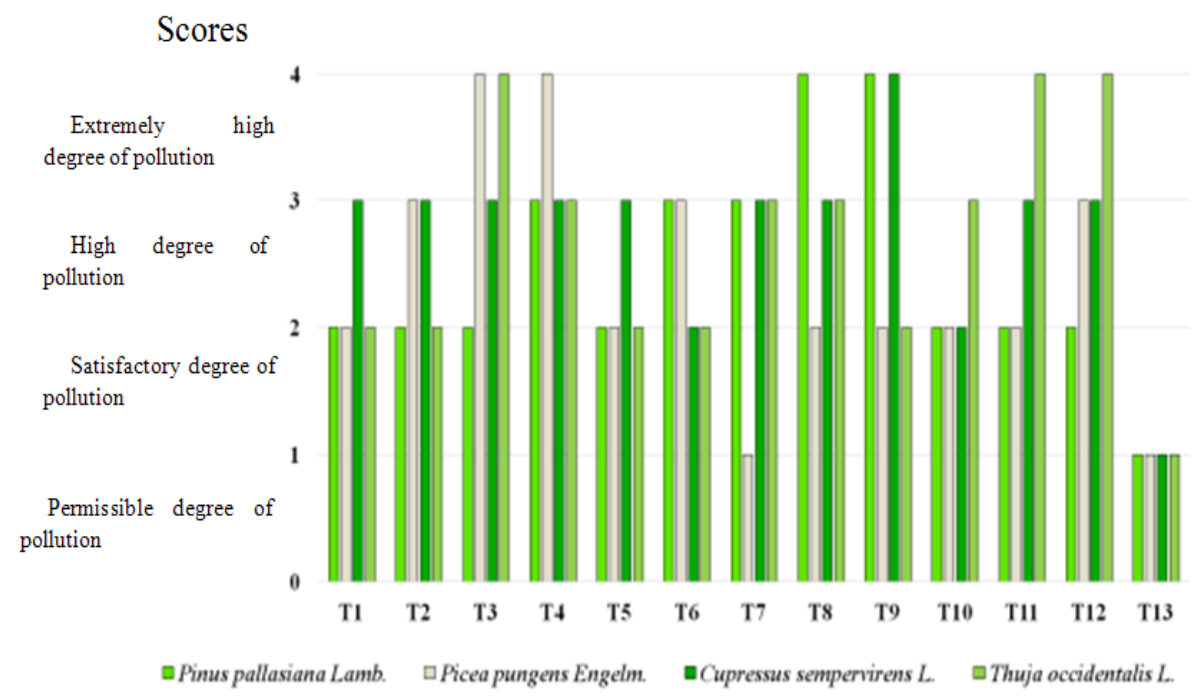

Fig. 6. Results of studies of peroxidase activity (I.II.I.7). 
In the study of catalase activity (EC 1.11.1.6), thuja occidentalis confirms the ranking, the Mwditerrenian cypress did not confirm the ranking of points (Fig. 7).

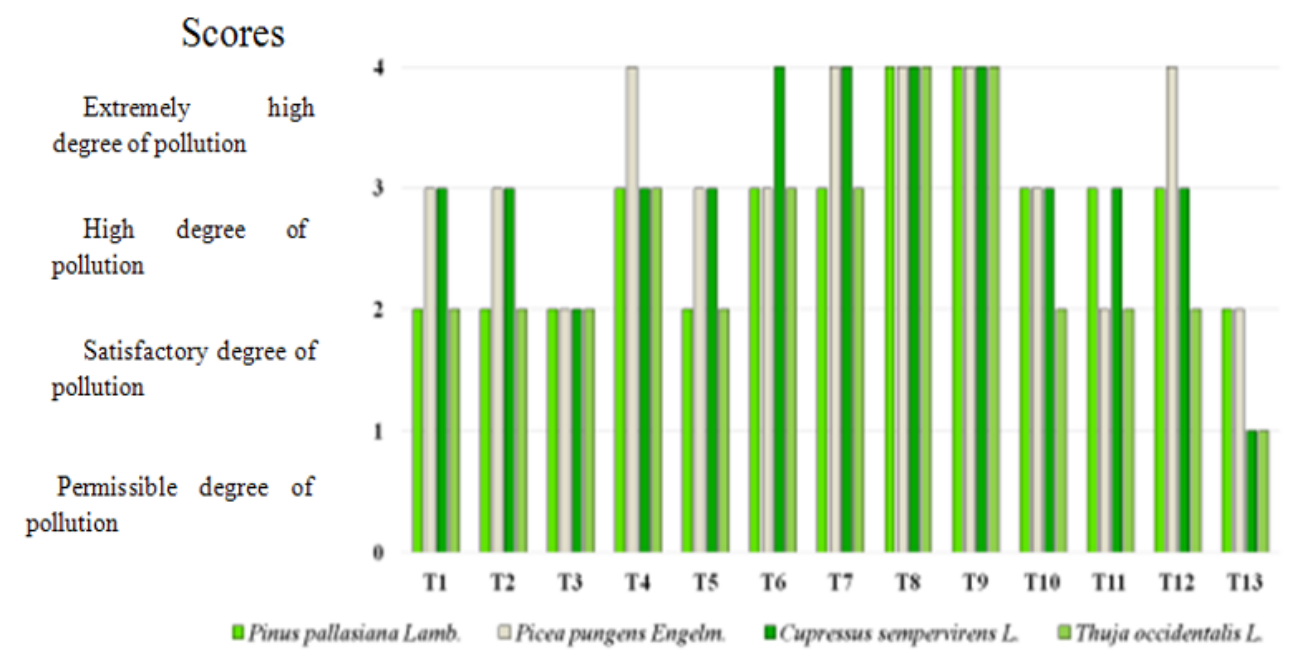

Fig. 7. Results of studies of catalase activity (I.II.I.6).

According to the results of studies of the content of ascorbic acid in the needles, the Crimean pine confirms the ranking of points, the mediterrenian cypress did not confirm the ranking (Fig. 8).

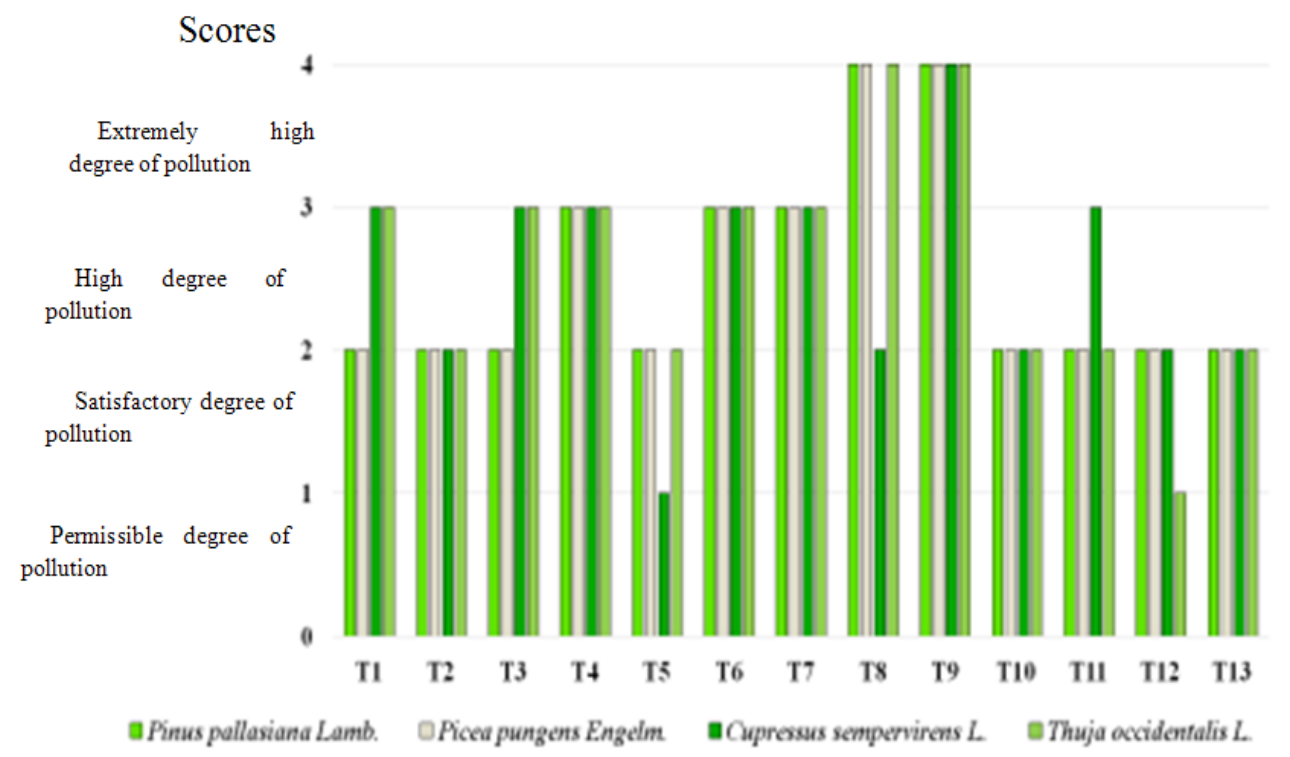

Fig. 8. Results of studies of the content of ascorbic acid.

At the third stage, chemical indicators of tree plantations at each of the selected points were used as markers [32-38].

When studying the formation of organic matter in the needles, the Crimean pine confirms the ranking, the American arborvitae did not confirm the ranking. The results are summarized in Fig. 9. 


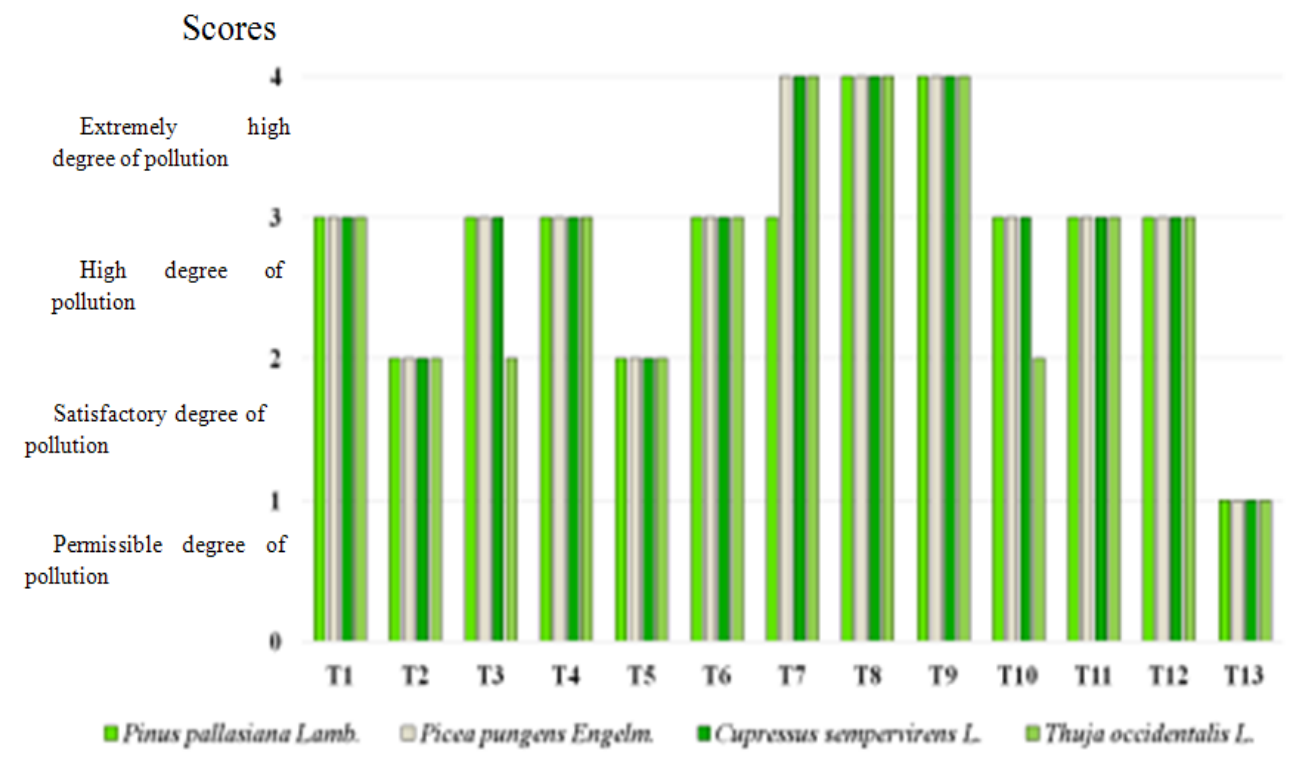

Fig. 9. Results of studies of the formation of organic matter in needles.

According to the results of studies on the content of chlorophyll in needles, the Crimean pine also confirms the ranking of points, the Midwterrenian cypress did not confirm the ranking (Fig. 10).

\section{Scores}

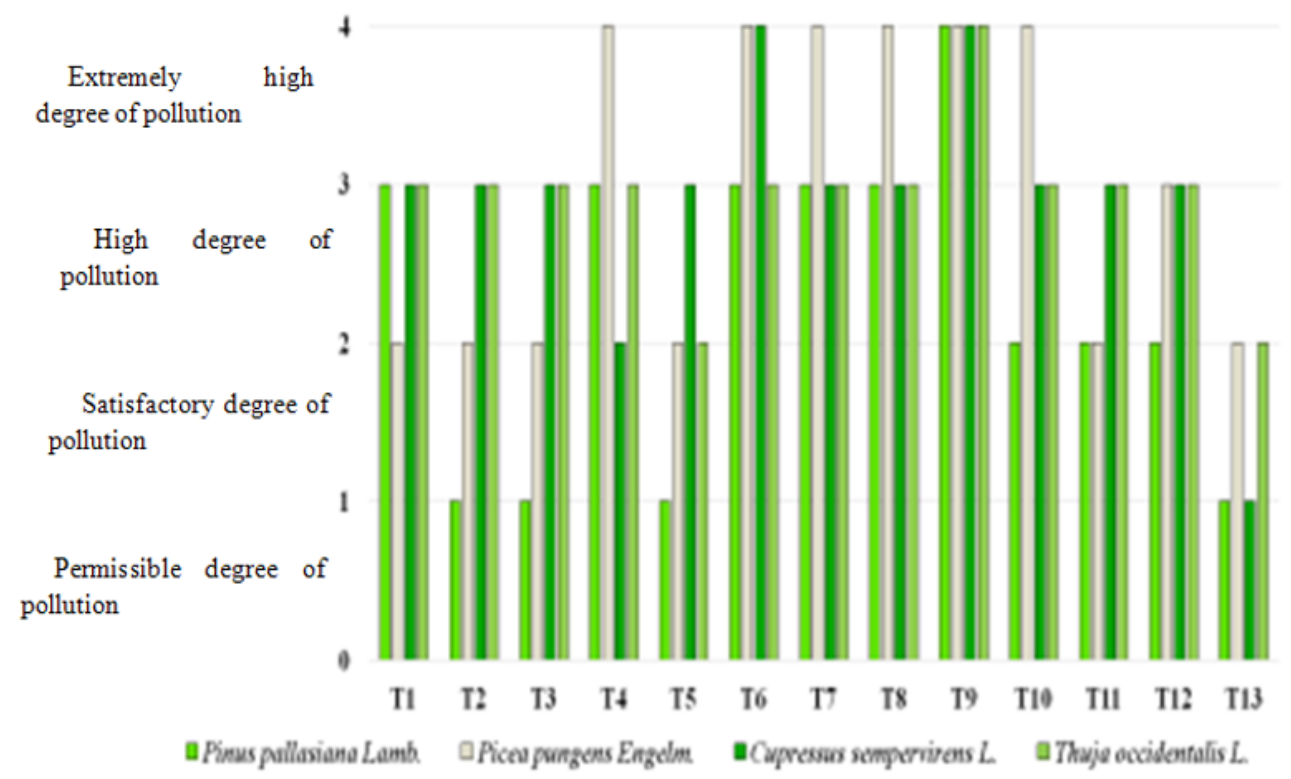

Fig. 10. Results of studies on the chlorophyll content. 
Thus, the results obtained confirmed the possibility of using Pallas pine as a test object for assessing the quality of the environment. The Mediterrenian cypress showed unequivocal results indicating a high degree of gas resistance of this conifer to the main pollutants, which excludes the possibility of using it as a bioindicator, but the results obtained allow this plant to be used for landscaping any areas of the city with the highest anthropogenic load.

Subject to a complete analysis of all stages of bioindication, coniferous dendroforms: blue spruce and American arborvitae showed results that allow their use in bioindication.

\section{Conclusions}

Nowadays, the instrumental method is most often used in the implementation of state control of the state of atmospheric air, but most gas analyzers do not provide the required measurement accuracy, and foreign analogues are usually expensive. As a control method, the most convenient and fairly cheap methods are bioindication and biotesting.

For bioindication and biotesting, it is necessary to use test objects that are sensitive to the selected parameters of pollution, in particular, for atmospheric air. Bioindicators should have a number of properties: be typical for a given territory; have a high number in the studied ecosystem; to use accumulating bioindication, test objects should grow in a given place for a number of years, to be in conditions convenient for sampling; have a short period of ontogenesis to determine the dynamics of pollution.

The obtained research results confirmed the possibility of using Pinus pallasiana Lamb. as a test object for assessing the quality of the environment. Cupressus sempervirens L. showed unambiguous results, indicating a high degree of gas resistance of this conifer to the main pollutants, and, as a consequence, the impossibility of using it as a bioindicator. Coniferous dendroforms Picea pungens Engelm. and Thuja occidentalis L. showed results that allow their use in bioindication, in the case of using the entire possible spectrum of markers to increase the reliability of environmental quality assessment by bioindication and biotesting methods.

\section{References}

1. Alexandrova M S, Batalova M Z, Kravchenko E.I., Pugolovkina O B Development of the air quality control system [Electronic resource] URL: https://elibrary.ru/item.asp?id=12500312.

2. Baltin R R , Krasnov A N Development of an automated air quality control system [Electronic resource] URL: https://elibrary.ru/item.asp?id=27494324

3. Baltin R R., Krasnov A N Development of an automated air quality control system [Electronic resource] URL: https://elibrary.ru/item.asp?id=27494324

4. Lyashenko O A 2012 Bioindication and biotesting in environmental protection: textbook (St. Petersburg: GTURP) p 67

5. Melekhova O P , Egorova E I et al 2007 Biological control of the environment: bioindication and biotesting (M.: Publishing Center "Academy") p 288

6. Bioindication, its levels [Electronic resource] Access mode http://biofile.ru/bio/22458.html

7. Neverova O A 2006 Experience of using bioindicators to estimate the pollution of environment: analitycal review Ser. Ecology Issue 80 ed O A Neverova, N I Eremeeva (Novosibirsk, State public scientific and technical library of the Sib. branch of RAS, Institute of Human Ecology) 88 
8. Annual report on the state and protection of the environment of the federal city of Sevastopol for 2019

9. The results of the work of the environmental inspection for the first quarter of 2018 URL: http://ecosev.ru/

10. Kosovskaya M A 2018 Express assessment of the state of atmospheric air by bioindication and biotesting of dendroforms. Technosphere safety systems: materials of the $V$ All-Russian conference and school for young scientists (with international participation) (Taganrog) pp 200-202

11. Tucker G 2000 Species presence. Agri-environmental indicators for sustainable agriculture in Europe ed D M Wascher (Tilburg : ECNC) pp 103-113

12. Klevtsova M A, Phan Thi Lan Anh The bioindication state of environment of the urban areas [Electronic resource] URL: https://elibrary.ru/item.asp?id=26737720

13. Tarasova T F , Aleeva O N, Pavlova T V Assessment of the ecological state of the territory adjacent to the Olkhovskoye field, using the bioindication method [Electronic resource] URL: https://elibrary.ru/item.asp?id=25766071

14. Pavlyuk P A, Petrov V D, Kadutsky A A, Gerasimova L A Bioindication of atmospheric pollution of certain regions of Krasnoyarsk [Electronic resource] URL: https://elibrary.ru/item.asp?id=25777828

15. Onofreychuk O N Population-specific bioindication in the assessment of the urban environment (using the example of an average city) [Electronic resource] URL: https://elibrary.ru/item.asp?id=28156780

16. Yakisheva Yu E Assessment of the level of atmospheric pollution in Yekaterinburg by the bioindication method [Electronic resource] URL: https://elibrary.ru/item.asp?id=28334788

17. Galibina N A, Tselischeva Yu.L., Andreev V.P., Sofronova I.N., Nikerova K.M. Peroxidase activity in organs and tissues of silver birch trees [Electronic resource] URL: https://elibrary.ru/item.asp?id=19872009

18. Korshikov I I , Vinogradova E N Changes in the physiological and biochemical parameters of the leaves of Acer platanoides L. and Acer pseudoplatanus L. trees differing in resistance to exhaust gases in plantations along the highway [Electronic resource] URL: https://elibrary.ru/item.asp?id=37266867

19. Nikolaevsky V S 1999 Environmental assessment of environmental pollution and the state of terrestrial ecosystems by phytoindication methods (Moscow: MGUL) p 193

20. Grudeva L I , Tinnikova A V Bioindication of the state of the atmosphere in some areas of the city of Abakan [Electronic resource] URL: https://elibrary.ru/item.asp?id=25425641

21. Milyutina I L, Sudachkova N V , Romanova L I The response of the antioxidant system of light-loving and shade-tolerant pine species to phytocenotic stress [Electronic resource] URL: https://elibrary.ru/item.asp?id=18928435

22. Neverova O A, Legoschina O M, Bykov A A Assessment of the intensity of oxidative processes in woody plants in the area of industrial emissions [Electronic resource] URL: https://cyberleninka.ru/article/n/otsenka-intensivnosti-okislitelnyh-protsessov-udrevesnyh-rasteniy-v-zone-deystviya-promyshlennyh-vybrosov

23. Neverova O A 2004 Ecological assessment of the state of woody plants and environmental pollution of an industrial city (example of Kemerovo): abstract of thesis of Dr. in Biology (Moscow) p 37

24. Nikolaevsky V S 1999 Environmental assessment of environmental pollution and the 
state of terrestrial ecosystems by phytoindication methods (Moscow: MGUL) p 193

25. Neverova O A 2001 Bioecological assessment of atmospheric air pollution by the state of woody plants (Novosibirsk: Nauka) p 119

26. Ignateva O V 2005 Elemental composition of needles and morphophysiological parameters of Scots pine (Pinus sylvestris L.) under conditions of technogenic pollution: abstract of thesis of Ph.D. in Biology (Krasnoyarsk) p 18

27. Rozhkov A S 1989 Effect of fluorine-containing emissions on coniferous trees ed A S Rozhkov, T A Mikhailova (Novosibirsk: Nauka) p 157

28. Bogolyubov A S, Buivolov Yu A, Kravchenko M V 1999 Assessment of the vital state of the forest from pine ("Ecosystem") [Electronic resource] URL: https://mducekt.mskobr.ru/files/bioindikaciyaya_po_sosne.pdf

29. Kosovskaya M A , Khrenova T K , Klimova Yu Yu 2017 Analysis of the activity of antioxidant enzymes of woody plants under conditions of local exposure to exgalates using the example of Sevastopol In the collection: Environmental, industrial and energy safety

30. 2017 Collection of articles based on the materials of a scientific and practical conference with international participation Ed Yu A Omelchuk, N V Lyamina, G V Kucherik pp 670-678

31. Kosovskaya M A, Khrenova T K , Bibikova V V 2017 Analysis of the activity of peroxidase and catalase in tree plantations under local exposure to exgalates Power plants and technologies 3 No 1 83-94

32. Chlorosis and necrosis of trees [Electronic resource] URL: http://ecoclub.nsu.ru/books/Obr3-4/14.htm

33. Voskresenskaya O L, Sarbaeva E V, Starikova E A, Changes in the activity of antioxidant enzymes in introduced conifers in an urban environment [Electronic resource] URL: https://cyberleninka.ru/article/n/izmenenie-aktivnosti-antioksidantnyhfermentov-u-introdutsirovannyh-hvoynyh-rasteniy-v-usloviyah-gorodskoy-sredy

34. Determination of ascorbic acid by iodometric method [Electronic resource] URL: https://studfile.net/preview/5063908/

35. Balandaikin M E Correlation of the content of ascorbic acid in the assimilation apparatus of Betula pendula Roth. with the action of a pathological agent [Electronic resource]

URL:

http://turczaninowia.asu.ru/index.php/cw/article/download/jcprm.1401153/190

36. Kolmogorova E Yu 2011 The intensity of the synthesis of secondary metabolites in the needles of Scots pine growing in the conditions of the waste dump of the Kedrovsky coal mine Ecological problems of industrial cities: collection of scientific papers Rart 2 ed. E I Tikhomirova (Saratov) pp 127-129

37. Kosovskaya M A, Litvakova E D 2017 Possibility of using morphophysiological indicators of wood plants in bioindication of urban environment pollution Int. scientific - technical Conf. NATURAL DISASTERS AND HUMAN LIFE SAFETY (Baku: Ministry of Education, of Azerbaijan Republic, Azerbaijan University of Architecture and Construction) p 270

38. Kozlov G, et al 2019 Phenatrene biodestructors isolated from soils of large cities E3S Web of Conferences 13501052 doi:10.1051/e3sconf/201913501052 